\title{
Recycling of Textiles in Historic Contexts in Europe Case Studies from 1500 BC till 1500 AD
}

\author{
Karina Grömer
}

DOI: $10.17234 / 9789531757232-05$

Introduction: What is textile recycling?

Recycling is a term, nowadays used for various actions, usually meant as a key component of modern waste reduction. There are some more meanings of the term recycling, as demonstrated by the official definitions of recycling after Dictionary.com (http://www.dictionary.com/ browse/recycle, accessed: March 31, 2017):

a) to treat or process (used or waste materials) so as to make suitable for reuse

b) to alter or adapt for new use without changing the essential form or nature of

c) to use again in the original form or with minimal alteration

d) to pass through a cycle again; repeat a process from the beginning

To explain that with modern examples (see e.g. https://en.wikipedia.org/wiki/Textile_recycling, accessed: March 31, 2017): For modern consumers the most common way of recycling textiles is reuse through reselling or donating to charity, e.g. to Salvation Army (https:// en.wikipedia.org/wiki/The_Salvation_Army, accessed: March 31, 2017) or Caritas (https:// en.wikipedia.org/wiki/Caritas_Internationalis, accessed: March 31, 2017). In such ways donated textiles are treated in various different ways. One the one hand, they can be resold; therefore they are sorted by color, size and quality, then packed, baled and sold as good reusable clothing.

Some textiles can be re-made into other pieces of clothing. Interesting examples of that kind of textile recycling are among the Do-it-Yourself (DIY) movement - people, who are building, repairing and modifying things without the direct aid of experts or professionals. A new platform for DIY is the world wide web. Thus, via internet creative designs are spread, such as to refashion old blue jeans into skirts or bags (e.g. https://de.pinterest.com/pin/764486105465629026/ or http://wonderfuldiy.com/wonderful-diy-10-ways-for-transformation-of-the-old-jeans/, accessed: April 28, 2017). Those ideas are posted e.g. on Pinterest or on websites and blogs, inspiring millions of people worldwide. (Fig. 1).

In modern textile recycling companies, damaged textiles are sorted out and converted into rags to make industrial wiping cloths and other items. Textile fibers can also be processed: Fiber reclamation mills grade incoming material into type and color. The textiles are shredded into "shoddy" fibers and blended with other selected fibers, depending on the intended end use of the recycled yarn. 
In prehistoric and historic times (this study covers roughly the period between $1500 \mathrm{BC}$ and $1500 \mathrm{AD}$ ) textiles have been produced for various purposes, one important among that is clothing, worn in daily life or for specific occasions. Textiles also have been used for funeral practices or as soft furnishings such as wall hangings, cushions or pillows (Grömer 2016: 291-318). There are also various possibilities, how textiles have been recycled and re-used within that time-span. Among them, some case studies are presented.

Re-use and recycling of garments

As evidenced by prehistoric and historic finds, garments have been treated in various ways: re-used in a different context, re-worked and still be used as clothing; garments have also been totally made of recycled material; also worn-out garments have been re-worked to serve for other purposes. Usually it is not easy to prove that on archaeological material due to the fragmentary state of most archaeological finds. In rare cases, also complete garments survived and those are valid for our further examples.

\section{Re-working of garments in prehistory}

Spectacular and well known finds of complete garments are known from Bronze Age Denmark, in particular from the peninsular Jutland, $14^{\text {th }}$ to $12^{\text {th }}$ centuries BC (Broholm \& Hald 1935; Hald 1980; Bergerbrant 2007; Mannering et al. 2012). In Oak coffin graves complete outfits of women have been preserved, comprising blouses, skirts, belts, large wrap-around garments (blankets) and hairnets. In men's graves cloaks, smaller and irregular shaped wrap-aroundgarments, leather and textile belts have been found.

The specific shape of men`s wrap-around garments and kidney-shaped cloak especially caught the attention of some researchers. The cut pattern (Fig. 2) - how to tailor those two garments is striking: Firstly, the kidney-shaped cloak is cut out from a larger piece of cloth. The remaining part is of an irregular stripy shape with prolonged ends. That piece is cut into larger and smaller pieces and then put together again to form the more or less rectangular men's wrap around garment. It is an interesting fact, that the total amount of cloth needed for that cut pattern has the same size as the larger wraps ("blankets") found in graves of women. Thus, it was thought, that maybe men's garments might have been made out of garments that formerly have been worn by women (Eskildsen \& Lomborg 1977; see also cut pattern in Munksgaard 1974; Randsborg 2011: 64).

\section{Special case: re-use of high quality garments for liturgical vestments}

From Medieval and Early Modern Europe a specific re-use of textiles is known, comprising a high-ranked context. It was common among the European elites to donate valuable textiles such as wedding garments or other precious cloth to the Catholic Church (Stolleis 2001: 15; Clegg Hyer 2012). They have then been made into ecclestical garments such as chasubles, stoles, copes or maniples. Such liturgical vestments are still kept in many European churches and monasteries, but also in costume collections. In some cases, still the donating persons as well as the former use of those textiles are known.

For example, in AD 934 the Anglo-Saxon king Athelstan donated some textiles to the shrine of St. Cuthbert near Durham in Great Britain. Among the precious gifts was also a gold-embroidered band that later was cut, sewn together and re-worked into a maniple. The former use of that band has been as clothing tie from a cloak or headdress of a piece of royal secular dress (Clegg Hyer 2012: 50-51 and fig. 3.1). 
Fig. 2: Cut pattern of Bronze Age male garments from oak coffin burials in Denmark (drawn by: K. Grömer, after: Munksgaard 1974 \& Schlabow 1937).
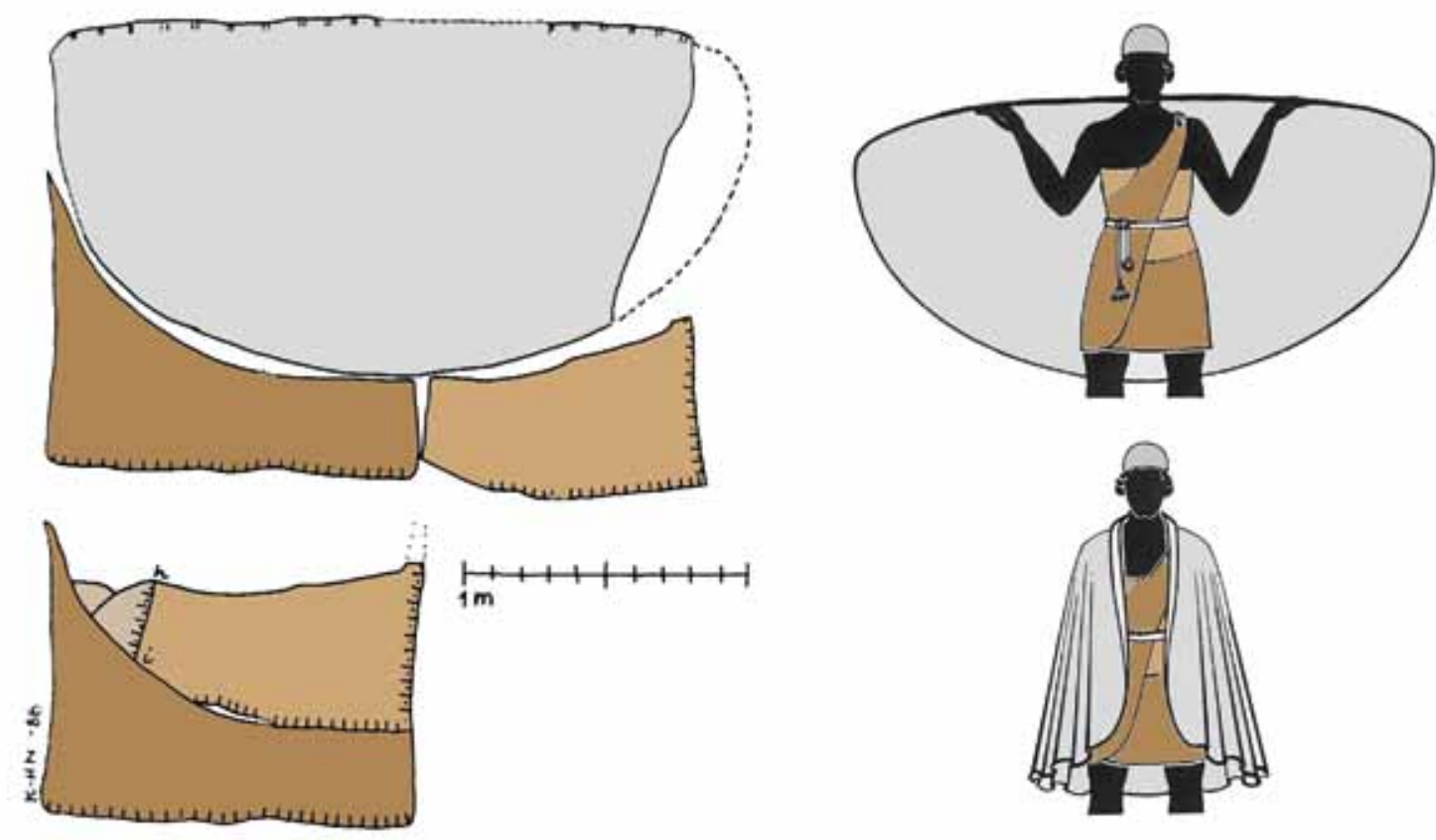

A striking example of re-use of donated textiles is a vestment kept at the Schnütgen museum in Cologne, Germany (Sporbeck 2001: 109-111). It is a chasuble made of a precious cloth, a red velvet with gold brocade in large floral pattern. Count Gumprecht II von Neuenahr is named as donator, after the death of his wife in AD 1459, he gave the textiles to the church. It can be clearly seen that the red velvet was former used as another type of secular garment, because the large piece that was needed for the chasuble was set together from various pieces of the same cloth, causing some cuts that disturb the large floral pattern.

Even the donation of a coronation-gown is documented from the St. Stephen`s cathedral in Vienna, Austria, given by members of the Habsburg family. Empress Karolina Augusta, the $4^{\text {th }}$ wife of Franz I. from Austria donated her coronation-gown on $17^{\text {th }}$ January 1859 (Donin 1873: 515). The precious silk damask fabric of the gown is embroidered with silver threads. It has been re-made into a chasuble (Fig. 3), 4 dalmatics and a cope: the so-called Maiornat (Inventory St. Stephan 2003: Inventar-Ordner 48, No. 9001/2182). The fabric was used for decorative parts of the ecclestical garments.

Such a 'reuse' of valuable textiles, which were given to the church, is a well-known phenomenon. Particularly female members of royal families and the elite donated precious textiles to be made into liturgical vestments. Some chasubles are stored in St. Stephan's which were made from the wedding gowns of diferent members of the Habsburg family (e.g. Eleonorenkasel) (Catalogue St. Stephan 1997, 238 and 253). In 1647 new vestments were made, using these 'old' fabrics.

All kinds of cloth have been given to the church, there are also interesting cases that textiles and garments, brought from far away, have been re-used for ecclestical garments. From Braunschweig (Stolleis 2001: 17-18, fig. Kat.Nr. 5), a chasuble is known that has been made of a pre- 
Fig. 3: Liturgical garments, so called "Maiornat", , decorative parts made of a coronation gown, donated to St. Stephan's cathedral in Vienna by the Habsburg family: chasuble and detail of a cope (copyright: St. Stephan's cathedral).
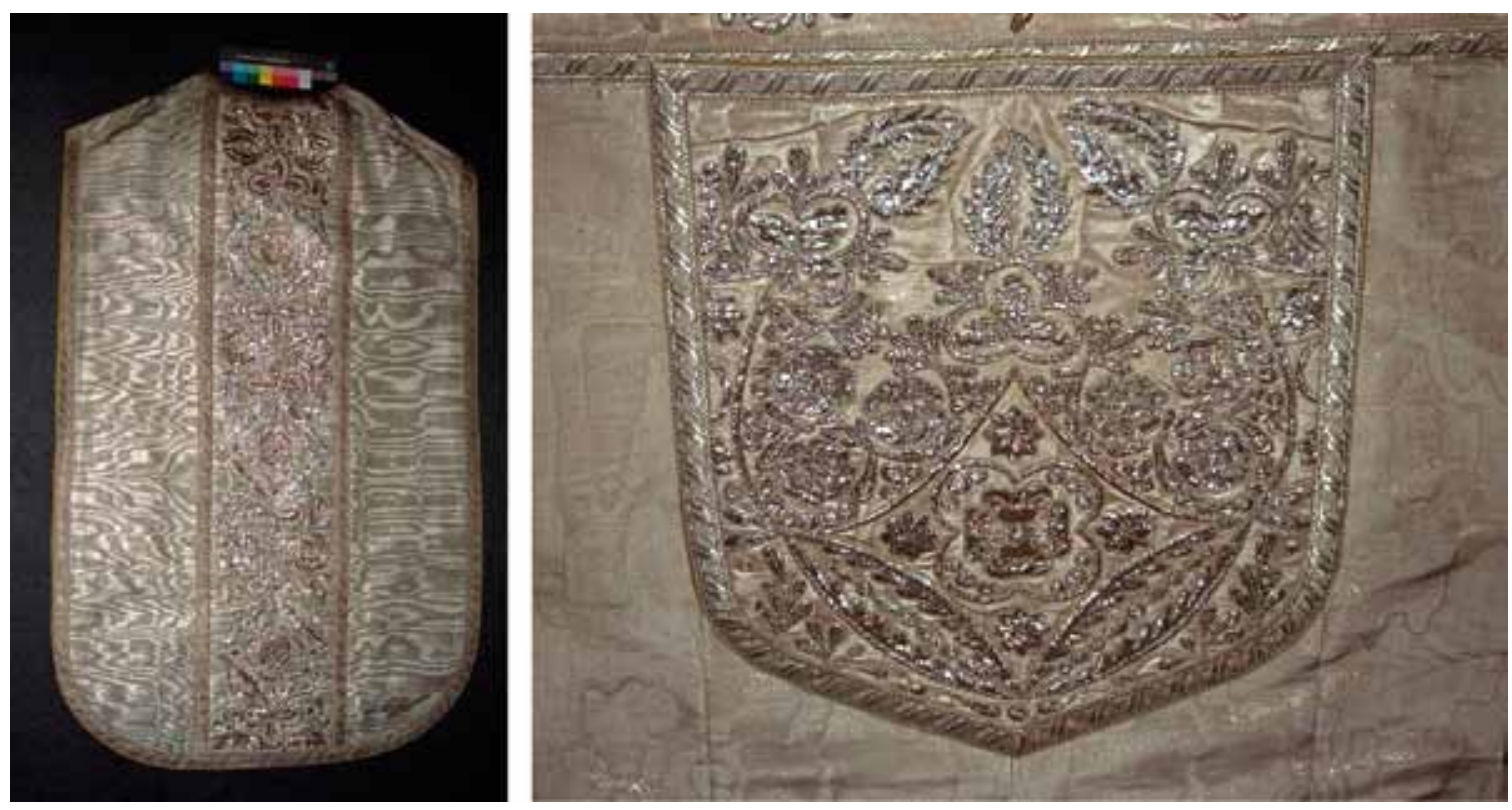

cious silk fabric with woven-in Arabic letters which praise Allah and the glory of a sultan. Definitely, the person who donated that fabric c. in AD 1430/1440 did not understand the letters. For him, it was just a precious fabric, worth to be re-worked as liturgical Christian garment. The silk cloth originated from the Near East and dates c. AD 1300.

\section{Garments in graves}

If we assume, that clothing is something to be worn in daily life, textiles used as shrouds or clothing in graves can be discussed as re-use. Usually we don`t know if the textiles we find there have been especially made for a grave purpose. Only in specific cases we know that textiles in a grave have been woven directly for that. The Iron Age tomb of Eberdingen-Hochdorf in Germany (Banck-Burgess 2012a, b) is such a case. In this grave, a c. 40-year-old male member of the Hallstatt elites had been buried together with precious grave goods. Among them are a gold-plated torc, amber jewelry, bronze dishes, drinking horns, a large cauldron with lions, a couch and a four-wheeled wagon. In the richly furnished burial chamber a number of precious textiles have been found, also the deceased was wrapped into several layers of cloth. Microscopic analysis of the textiles, such as fibre analysis brought to light, that the textiles might have been exclusively made for this tomb. A hint for this hypothesis is e.g. that fine badger fibres have been used to weave fine cloth such as tablet woven bands, while the coarse hair of badgers were found as stuffing of mattress and pillow (Banck-Burgess 2012a: 142-143). The coarse badger hair has been sorted out and separated from the fine under-coat of the badger before spinning and weaving fine cloth. As that kind of raw material is quite unusual, and artefacts deriving from different steps of processing the hair are found together in the grave, it has been interpreted to be made at the same time and for the same purpose, i.e. for the burial.

From archaeological finds, there are also hints that garments from daily life have been re-used for dressing the dead. Former use of a burial garment in daily life can be attested through tear and wear. 
Among the afore-mentioned Bronze Age grave finds of complete garments in Denmark, some of them have mended parts, thus pointing to a longer use during life-time (Broholm \& Hald 1935: fig. 56 and 68; Mannering et al. 2012: 101). One of such repaired examples comes from the female grave from Egtved. Also the blouse from Borum Eshøj displays some weak parts at the sleeves, deriving from heavy use.

From Iron Age, bog bodies have been found in Northern Europe, e.g. in Denmark and SchleswigHolstein (Northern Germany). There has to be differentiated between people who have been buried in the bogs and persons who have been victims of accidents (Van der Sanden 1996, chapter 7). The latter ones of course wear their daily garments, whilst the garments of buried people have been selected for the funeral purpose. Some of the bog bodies deriving from a burial wear garments that have been repaired. A good example is the find discovered in 1949 at Hunteburg in Northern Germany (Möller-Wiering 2012: 161). The calibrated 14C dates vary between 245 and 415 AD. The bodies of two men lying side by side have been wrapped into large cloaks with marks of repair (Schlabow 1976: 51-53 and fig. 74). Cloak A of Hunteburg displays a damaged tablet woven border which had been torn and then fixed with secondary stitches to make it wearable again. Another type of use-wear was identified with the cloak B of Hunteburg. In the centre of the garment, layers of mending-stitches are visible, covering a huge area (Fig. 4). When worn, that part of the cloak is laid on the shoulder, precisely, there it was fixed with a fibula. Thus, the penetration with the fibula, done daily when taken on, caused massive damage and weakening of the cloth. That has been met with mending the damaged area several times. Such, we can assume that this cloak has been worn long time during life-time, before it ended up to cover the dead body. Another example of the use of a heavily worn costume as grave garment for a dead person can be named from Dätgen in Germany. The clothes of the Dätgen body (Schlabow 1976: 55-57, fig. 83; Möller-Wiering \& Subbert 2012: 161), which date to cal AD 345-535, consist of trousers and a worn-out cloak. The cloak has been mended and patched also due to the use-wear, it has been cut off and thus the original size of the cloak was reduced.

Interesting hints for the re-use of a garment worn during life-time in a grave can even begained from entomological analysis. Thus, a textile found on a bracelet of a Roman Period child's burial in Furth/Göttweig in Austria (Grömer 2014: 232 and Taf. $20)$, dated to the $4^{\text {th }}$ century AD, displays an interesting evidence for our question: When microscopic analysis of the textile was carried out, also a human body louse (Pediculus humanis corporis) have been found (Fig. 5). The textile fragment was attached on the inner side of the bracelet and thus indicates that it formerly belonged to a sleeve of a tunic. Roman terms for garments are well known - a long-

Fig. 4: The cloak of Hunteburg bog body B with marks of repair on the shoulder (after: Schlabow 1976: fig. 74).

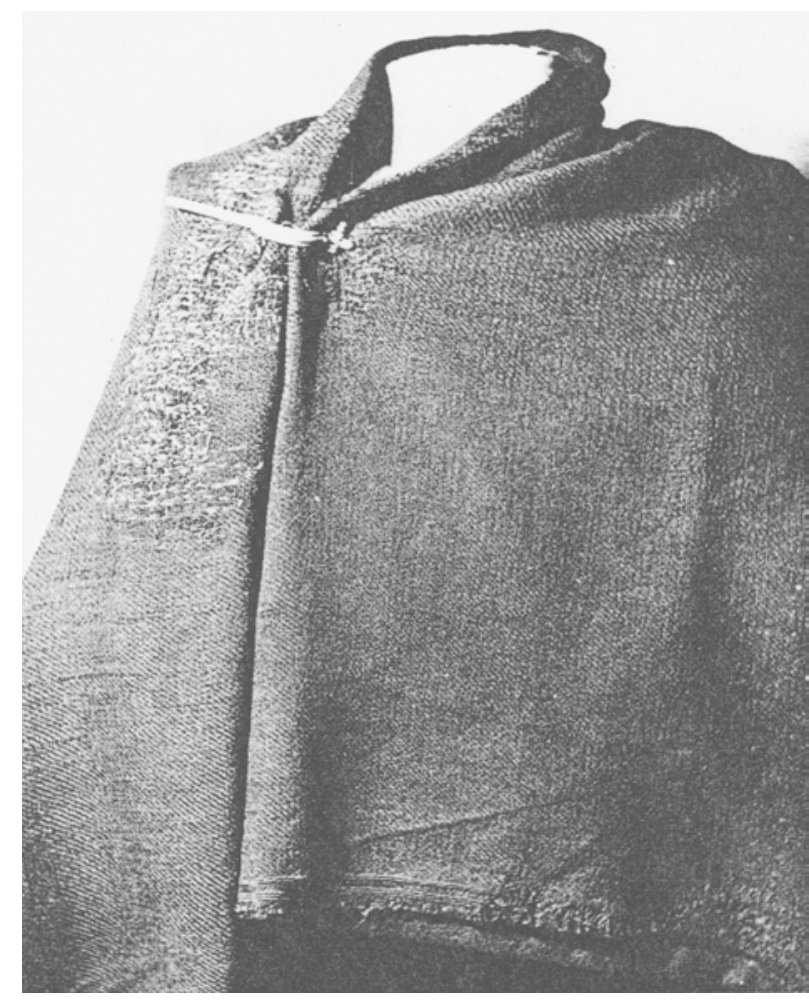


Fig. 5: Textile from a roman childs burial from Göttweig, Austria, with human body lice (after: Grömer 2014).
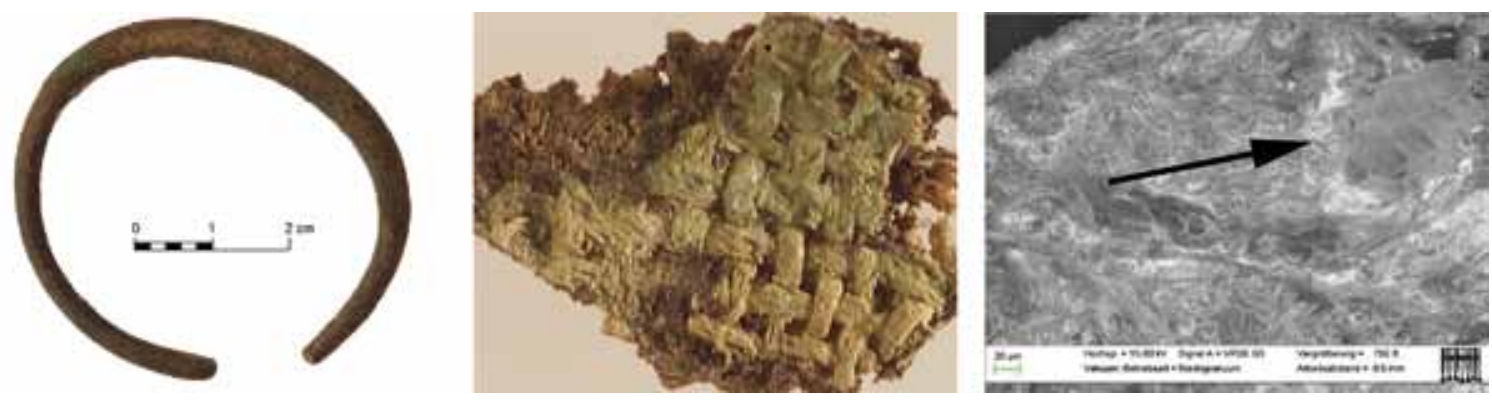

sleeved tunic is a tunica manicata. As body lice depend on living human beings to survive, we know that this specific tunica manicata also was worn during lifetime - whether by that person buried with it or another one can not be proved.

In the cases of graves garments which can be proved that those have been made for to be worn during life-time, we can state a re-use: Although it is still used as a garment, the function of the textile is not the same - the context is different. It is not any more worn, taken on and off by a living person, but buried with the deceased.

\section{Re-use of rags for garments}

Throughout history, rags have also been used for creating garments - that usually is a sign of low economic background and poverty. To point again to a more modern example - the borotextiles in Japan (Koide \& Tsuzuki 2008): It is a term, deriving from Japanese boroboro (something tattered or repaired) and meaning a heavily mended garment patched with recycling material or a garment one made out of scraps or recycled rags. In the Edo-Period (roughly $17^{\text {th }}$ till $19^{\text {th }}$ centuries AD) the economic background of the low social classes has been quite poor. Thus, peasant farming classes made their garments with spare fabric scraps out of economic necessity. In many cases, the usage of such a boro garment would be handed down over generations, eventually resembling a patchwork after decades of mending.

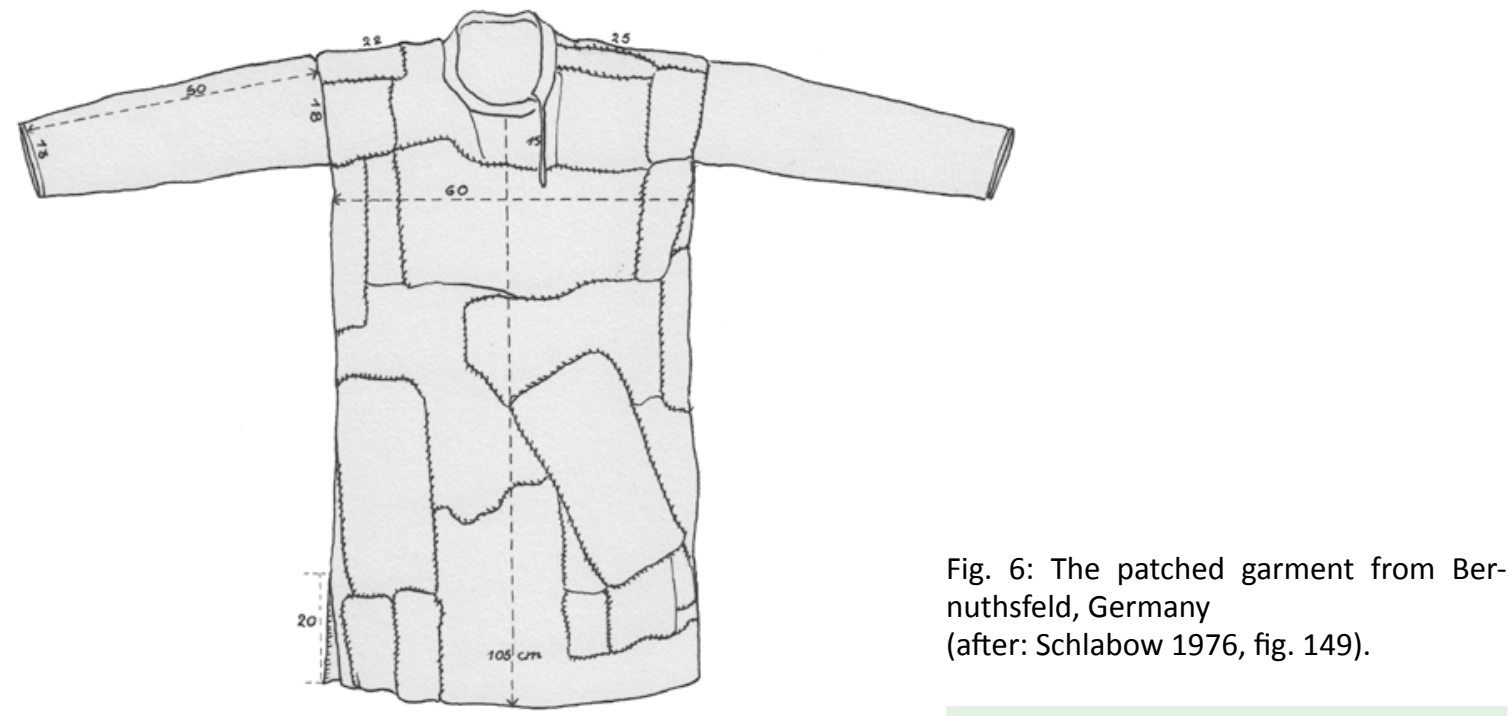


Fig. 7: Recycled textile in Hallstatt, Austria (HallTex 97) (@ Natural History Museum Vienna; photo: A. Rausch).
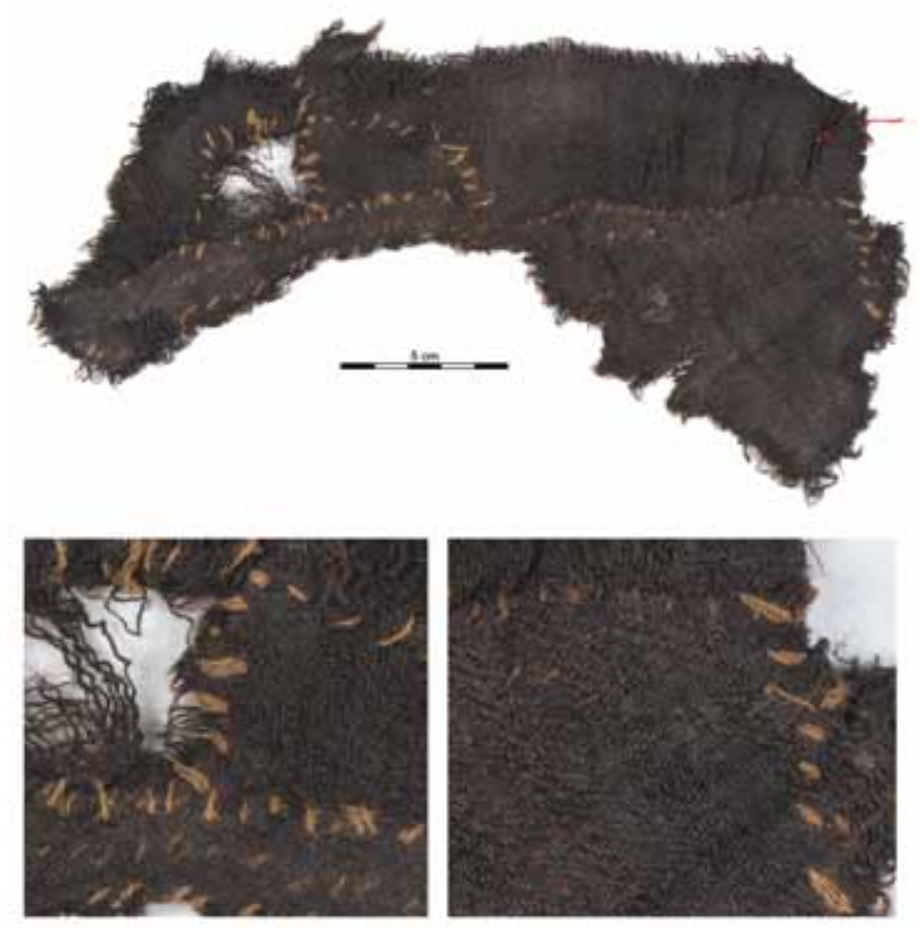

For prehistory and early medieval Europe, complete textiles are rare: There is only one garment that can be proved totally to be made of rags; the tunic of Bernuthsfeld in Germany (Fig. 6) (Schlabow 1976: 72-73, Fig. 149; Farke 2001). It was found in a bog on a man`s body, who also wore a fringed cloak, a pair of puttee-like leg-bindings and a plaid. Recent C14 dating (1290+-45 BP, ca. AD 660) has shown that it is not an Iron Age bog body as it has been published before, but comes from the Early Medieval period. All parts of the men`s costume show clear signs of wear and damage. As they are patched and mended, they presumably have been used for a long time. Of specific interest here is the tunic (Fig. 6) consisting of a patchwork of different weaves and weave qualities, among those are coarse to fine tabbies as well as twills of different qualities and types (simple twills as well as zig-zag or lozenge twill). A total number of 45 separate patches have been sewn together, which makes it seem as if the majority of the patches were the starting material of the garment. So recycled material - rags - are the foundation of the garment.

Massive patching can also be seen on the cloak of the Damendorf Man (Schlabow 1976: 54-55, fig. 76; Möller-Wiering \& Subbert 2012: 161) (Germany), dated to cal. AD 135-335. The garment was mainly made of diamond twill. Totally, there are 11 patches in various sizes attached, the smallest measuring $2 \times 2 \mathrm{~cm}$, the largest $11 \times 25 \mathrm{~cm}$.

\section{Re-use of garments for other purposes}

It is tricky to prove from an archaeological context that textiles, which formerly have been used as garments, have been converted into another artefact to be used for a completely different purpose. From the salt-mine Hallstatt in Austria some Iron Age textiles (c. 800-400 BC) have been found that clearly were used as garments, before they were re-worked and then ended up in the mine. A specific item is HallTex 97 (Grömer et al. 2013: catalogue, p. 423-425), a brownish twill fabric with several different stitches (Fig. 7). The analysis of the stitches clearly demonstrates different "hands" who made them. Firstly, there is a flat fell seam, carefully done with a thread that matches the main web in terms of colour and yarn diameter. The stitches 
of the seam are made very regularly. That seam might be the remnant of a garment. Also the overall appearance of the item places it among cloth to be used for garments: it is a patterned (spin pattern) twill fabric of fine quality, made of regular spun threads. After wear and tear it has been re-worked, it was torn, folded and roughly stitched together with up to three layers. The secondary seams and stitches have been carried out with other type of thread, a thicker yellowish one. The stitching is done irregularly, not with the same care that can be seen at the primary seam. Also the stitches with yellow thread superimpose sometimes the other ones (Rösel-Mautendorfer 2011: 73).

Nevertheless, even if the item looks quite chaotic, it is likely that an object for a specific purpose was produced. The stitches create a strong, multilayered flap in dimensions that fit very well into a human hand, also the hole, surrounded by stitches seems to be intentionally. The precise function of the object is difficult to determine due to the lack of comparable objects, but with that specific shape and the sewn hole it acts like a so-called Handleder. That is an item known from Hallstatt, usually round to rectangular in shape with a hole and made of leather. A Handleder is used to protect the palm when handling tools or ropes (Reschreiter \& Kowarik 2009: 57)

Textile rags for production of items

Rags of textiles have also been used as makeshift tools for various production processes. There is archaeological evidence for textiles used by potters, bronze-smiths and even for salt processing.

\section{Textile rags for pottery}

From different periods we have evidence that rags have been used for handling ceramic products during the making. Indicators are textile imprints on pottery. They must have originated during the work of the potter. Only if the fabrics were pressed into the not yet hardened clay (shortly after the shaping of the vessel) and the vessel afterwards has been fired, the textile imprints could remain until today. Whether specific fabrics were used for this purpose, or whether simply worn-out rags were used, can not be ascertained, but it is likely.

An imprint of a textile was found on the handle of a $2^{\text {nd }}-3^{\text {rd }}$ century AD vessel (Fig. 8) from the Roman settlement in Vienna, Austria (Grömer 2014: catalogue Rö-184 and plate 45). The textile impressed was a slightly rep-like tabby fabric of medium quality. Next to the textile imprints also the fingerprints of the potter can be documented. That evidence strengthens the interpretation that the textile probably has been a working tool of the potter. After the vessel was formed (but still in the damp state) obviously it was handled and touched using a cloth.

Sometimes also impressions of textiles or mats can be identified on the bottom of vessels. In that cases, the potter used the cloth as clean pad or support to keep the ready-formed vessels until they have been dry enough to fire them. One impressive example comes from Bilce Złote in nowadays Ukraine (Bender Jørgensen 1992: 84, fig. 110) and belongs to the neolithic Kultura trypolska, which roughly dates between 4200-2750 BC.

From the Early Middle Ages there are also finds for the use of textile rags in combination with a potter`s wheel. Certain imprints on the bottom of pots in Mikulčice and Olomouc in Czech Republic from the $9^{\text {th }}$ and $10^{\text {th }}$ century AD (Kostelniková 1972: Taf. I und II) can be interpreted such. It is likely that they functioned as a caulking of the axis of a potter's wheel, because they are pressed into the centre of the bottom piece in a special way. 


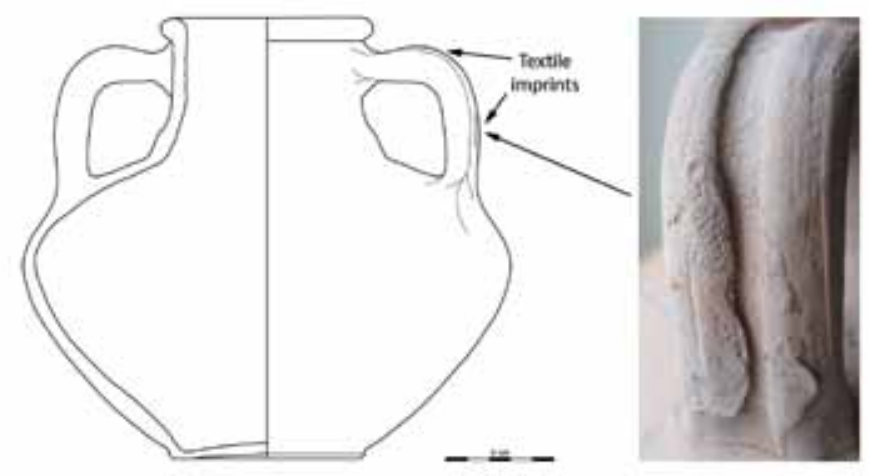

Fig. 8: Roman vessel from Vienna, Austria, with textile imprints caused by the potter (after: Grömer 2014, (C) Wiener Stadtarchäologie).

Textile rags not only comprised handling during the manufacture of ceramic vessels, but also for other products of clay such as bricks. On Roman bricks (Wild 1970: Tab. A/30, 33, Tab. $\mathrm{B} / 74$ ) sometimes impressions of fingerprints as well as of textiles are found, the latter can be interpreted as a mark of production-technological handling.

\section{Production of clay figurines}

Next to the use of textile scraps as make-shift materials for handling, fabrics also have been employed as material for stabilization.

That could be documented e.g. by scientific analysis of pipe-clay figures by craftsmen in the $15^{\text {th }}$ century in the Rhine area (Kaszab-Olschewski 2015). Many pipe-clay objects display textile structures which are preserved in the clay.; e.g. a St. Catharine-figure from 's-Hertogenbosch in the Netherlands.

The craftsmen in the Late Middle Ages used textiles to assist in the manufacture of their products. They worked on a high artistic level and persisted successfully in the $15^{\text {th }}$ century in competing with other arts and crafts producers (graphic artists, woodcarvers, etc.). They manufactured various ceramic objects such as larger figurines, reliefs and small statuettes which have been manufactured in series by applying negative or hollow forms (moulds). The statuettes were mostly produced by using separate moulds for the front and back sides by means of a two-part mould (like antique terracotta figures or today's Easter Bunny chocolate figures). The afore-mentioned textile traces are either concealed inside the objects or more or less clearly visible on the front- and backsides.

The textile inside helps to cake the individual layers of clay during the firing phase. The layers of clay sometimes differ in respect of consistency and material structure. The different claypastes with textile inserts allowed a sharper impression and prevented air bubbles in the product. The lattice structure of the fabric also had a stabilizing effect on the product.

\section{Production of jewellery and dress accessories}

Another type of use of recycled textiles for production processes can be observed from Iron Age and Early Medieval bronze-smiths.

Textile rags, together with other organic material were employed in the production of late Iron Age hollow rings. The hollow anklets and bracelets were made of very thin bronze sheets and decorated. They have been filled with clay, sand, wood or textile to stabilize the shape. This was an absolute necessity during the manufacturing, because the filling should protect the hollow body from buckling. After finishing the objects, the filling was not removed, because its shapeprotective properties also were utilized even during wearing. The textiles found in the hollow 


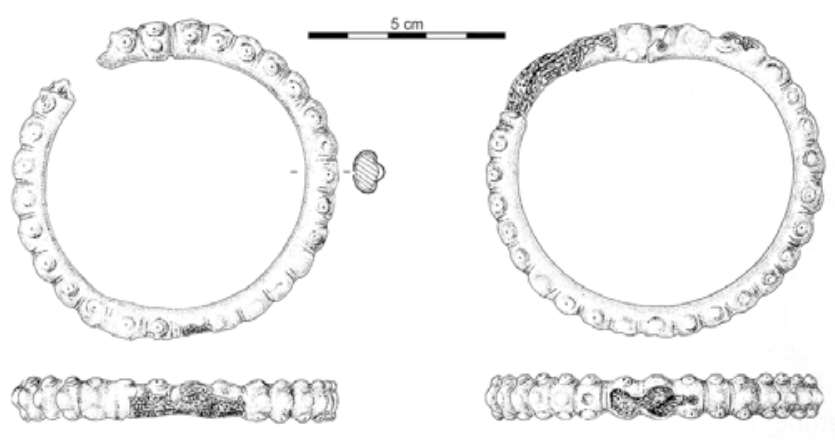

Fig. 9: Hollow rings filled with textile rags from Mannersdorf am Leithagebirge, Austria (after: Müllauer \& Ramsl 2007).

rings are always fragments of flax tabbies. Such objects have been excavated in the women's tombs of the Early and Middle Latène period, especially in Moravia and Slovakia (Belanová 2005; Belanová-Štolcová 2012: fig. 15.11-15.12), as well as in Lower Austria, for example in Mannersdorf am Leithagebirge (Fig. 9) (Müllauer \& Ramsl 2007).

As a special example, Grave 9 at Nové Zámky in Slovakia (Pieta 1992) is to be emphasized. In the two anklets of the women's burial, several fragments of a linen-woven fabric were discovered, which were decorated with red woolen embroidery. That piece of cloth definitely was primary made to be worn as a garment. Thus, it is obvious that we see here the "recycling" of old textiles. Additionally, it is also discussed in Slovakian research whether the textiles worn in a hollow body on the body could also have been textiles of a specific origin with a symbolic connotation or magical-ritual function.

A different use for recycled textiles was carried out for the production of Avar strap-ends in the Early Medieval. Strap-ends are an important part of a specific type of belts used by male members of the Avar Empire to represent wealth and social status. The strap-ends are highly decorated and in the $8^{\text {th }}$ century $\mathrm{AD}$ they have been made in the technique of bronze-cast. At the Avar cemetery Leobersdorf, Austria (Hundt 1987: fig. 1-2) strap-ends could be analysed that had impressions of a textile at the inner side of the object. What makes the textile structures outstanding, is that they have been casted in. Different theories arose, how a textile structure can appear from the bronze casting process and how this was done technically. Hans-Jürgen Hundt (1987: 10-17) used the method of experimental archaeology to reconstruct the production process. It was already known that the basis of casting those strap-ends have been wax models which were formed in clay or wooden models before. The wax models then have been coated in clay and fired, the wax melts, leaving a mold into which molten metal can be poured (lost-wax method). Additionally Hundt found out that a textile scrap (soaked with wax) has been attached to the back of the strap-end wax model, because the object is quite thin (to save later on casting bronze material) and thus it tends to break or to bend out of shape. The textile served to stabilize the wax model and as a distance-holder. When the casting was done, the textile structure was visible on the back of the strap end. Similar techniques for stabilizing thin wax models for bronze cast also has been identified among Scythian and Viking finds.

\section{Textiles used for briquetage}

At Erdeborn, Saxony-Anhalt in Germany, excavations brought to light an Early Iron Age site (Ipach 2015). The archaeological evidence and artefacts indicate, that on this site salt was produced from brine, using the briquetage-technique. Thus, densely packed ceramic vessels filled with brine are heated in kilns. As soon as the liquid vaporized, the salt crystals could be harvested and taken out of the vessels, which remain in thousand fragments on the site. During scientific investigation in some cases textile imprints could be found inside the vessel (Ipach et al. 2014). The textile traces are of different kinds - coarse tabbies, a twill cloth and a coarse 
veil-like fabric. They do not represent standardised fabric types as the vessel types are. Therefore it seems feasible that different kinds of rags that have been easily available have been used, and not textiles specifically made for that purpose.

Here also, experimental archaeology (Fig. 10) was applied to understand the function of the textiles. It was assumed that the textile rags could have been used in the production of the salt. They might have been inserted to serve as a layer between the briquetage-vessel and the salt clump which is gained after firing. This theory was proved by an experiment. If the brine is heated in a vessel layered with cloth, the salt crystallizes along the textile structure and such a clean salt piece can be removed from the vessel easily.

\section{Textiles as caulking material}

Caulking (e.g. https://en.wikipedia.org/wiki/Caulking, accessed: April 28, 2017) in a historic meaning is usually understood as to fill or close a seam, joint, etc., as in a boat. Thus, it is made watertight by filling the seams between the planks with oakum (hemp fibre soaked in pine tar) or other material driven snug. More general, the term caulking also means to seal joints or seams in various other structures and some types of piping. The same term also refers to fill or close seams or crevices e.g. of a tank, window, etc. in order to make watertight, airtight, etc. In a modern sense, caulking also means driving the edges of plating together to prevent leakage. Silicone or polysulfide caulking came up in the $20^{\text {th }}$ century, but even until recent days caulking has been done with textiles or half-finished products like bundles of roughly prepared flax or hemp fibres. The idea, to use properties of textile materials like flexibility and elasticity for making something wind- or waterproof can be traced back quite far in history.
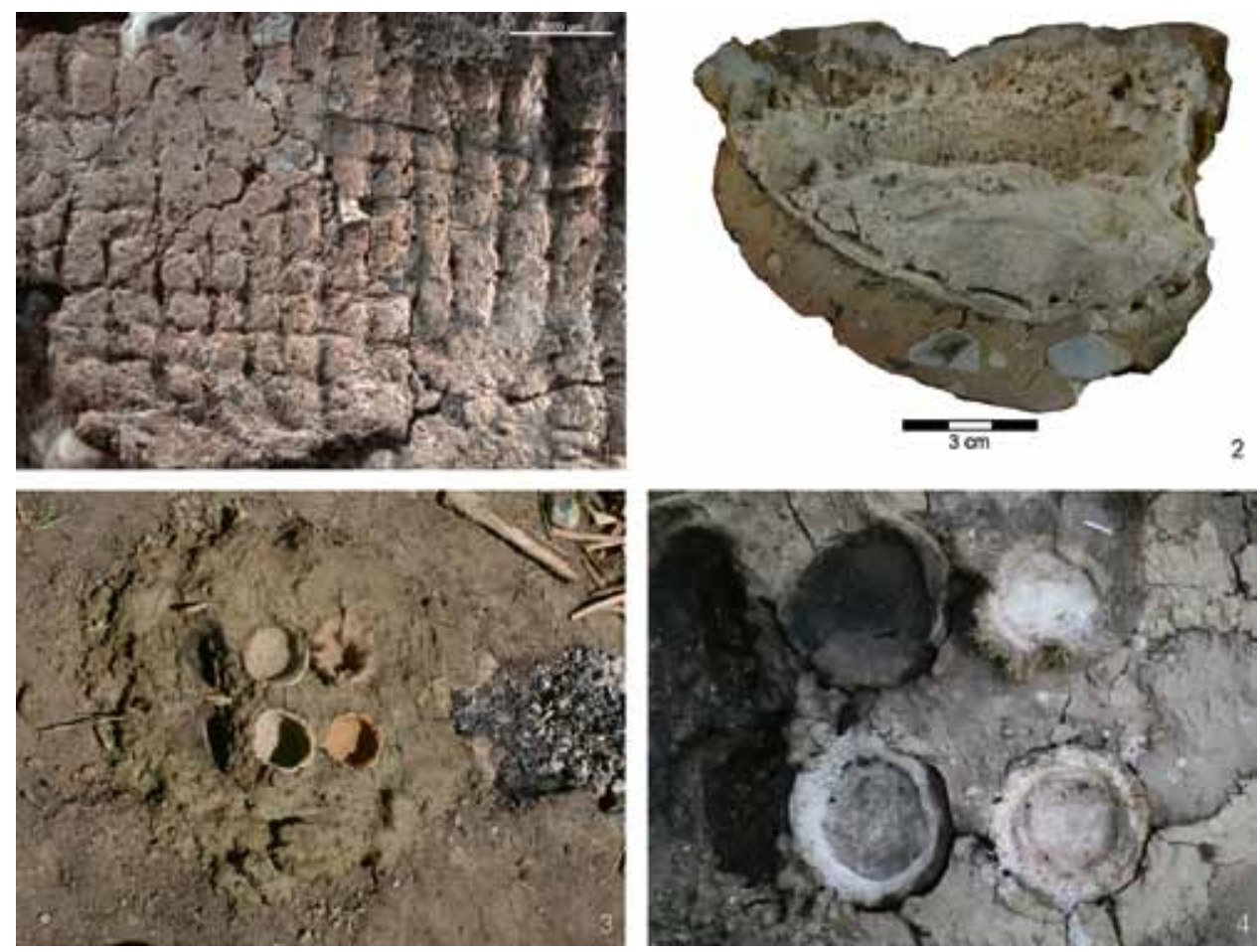

Fig. 10: Erdeborn, Germany: 1 Textile imprint on a briquetage-fragment, 2-4 Experiments. 2 cross-section of a vessel with textile and crystallized salt, 3 reconstruction of the briquetage-furnace, 4 crystallized salt from the heating process (after: Ipach et. al. 2014). 
Fig. 11: Mitterberg copper mine, Austria: wall of planks found in the $19^{\text {th }}$ century with textile caulking (after: Klose 1916 and Zschocke \& Preuschen 1932).

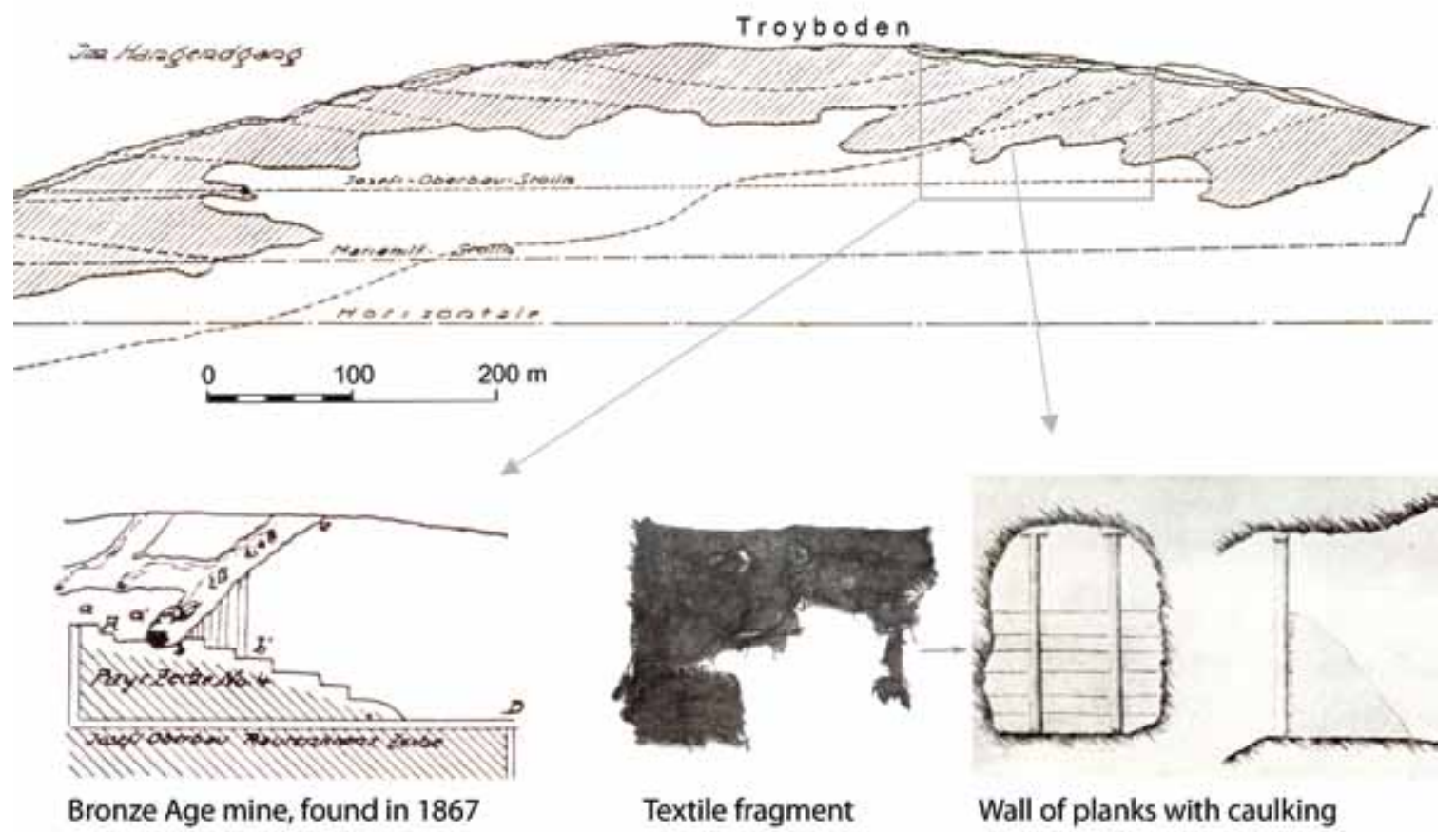

\section{Sealing for water-management in a copper mine}

At Mitterberg-Hochkönig in the Austrian Alps (Stöllner et al. 2009), a Bronze Age copper mine was found which was an important producer for raw copper especially in the second half of the $2^{\text {nd }}$ millennium BC. Different mining relics above and below ground have been explored such as the copper extractions in the mine and wet processing sites and smelting.

In the mine a wooden construction was found - a wall of planks had been erected up to half the height of the tunnes, supported by a stone sand deposit. As in other mines, at Mitterberg the miners had problems to manage unwanted water in the adits and tunnels. This protective device in the Bronze Age copper mine served as insulation against water, it should keep the invading day water from the part of the pit in which the miners were working. To even better serve that purpose, organic material was stuffed between the planks (Fig. 11). Among the caulking material also a textile (Klose 1916: 35, Abb. 45-46) was found, used as a sealing material. Textiles, especially items made of wool are very suitable for that purpose, because wool can absorb a lot of water and thus holding dry.

\section{Caulking wooden ships}

In historic times, ships were built with planks that are laid butting up against one another (carvel construction) or with planks laid slightly overlapping (clinker construction). The wood to wood joint of the carvel construction is narrow but cannot be clinched together, so that, those ships mainly rely on caulking the joints to make them water-tight. 
When in the $19^{\text {th }}$ century in Nydam (Möller-Wiering 2011) in southern Jutland, Denmark, boats were found in a bog, the preservation conditions have been excellent. The excavator Conrad Engelhard had the possibility not only to observe different technical details of how the ships were built, but he also detected woven caulking material from two ships: the oak ship (Nydam boat B) and the pine vessel (Nydam boat C), which unfortunately was destroyed shortly after the excavation. From his report (Engelhardt 1865: 7 and 12, translation in Möller-Wiering 2011: 93) we learn about the oak ship: "Between the planks where they cover each other, [the boat] is sealed with woollen cloth and a pitch-like and sticky matter." And concerning the pine vessel: "Underneath, there are patches of a sealing substance of woollen, woven cloth and a stichy, pitch-like matter which appears similar to that used for winding around arrow shafts." Nydam boat B was dated to AD 310-320. Recent analyses (Möller-Wiering 2011: 85-87) indicate the caulking textiles to be protected by some water-repellent matter. A variety of different fabrics have been used for caulking, such as tabbies or twills made of wool and plant material, also more elaborate textiles like diamond twill were used. All of them display different qualities, ranging from coarse fabrics to very fine ones. The textiles didn't belong to a specific type that might have been produced for that purpose. So, we can deduce that only recycled material textile rags - ended up as sealing material. The textiles have been heavily pressed between the wooden planks, that and the repellent kept the boat water-tight.

\section{Textiles for insulation of medieval castles}

In the course of modern renovation works in medieval castles, sometimes textiles, shoes and other rubbish were found below floorboards, in filled vaults and all kinds of holes in the stone walls (e.g. Nutz 2015).

One of the most impressive finds discovered in the last years, come from Lengberg castle in Tyrol, Austria (Nutz 2015). There, a vault filled with dry materials deposited in different layers was uncovered in the castle between the $1^{\text {st }}$ and $2^{\text {nd }}$ floor - an architectural feature dating to the $15^{\text {th }}$ century AD. The fill consisted of dry material in different layers, among them organic material such as twigs and straw, but also worked wood, leather (mainly shoes) and more than 2700 textile fragments. Among them are torn garments, also fragments of silks and a lot of colourful fabrics. Several fragments provide evidence for a secondary use. They were torn into strips and used as binding material, as some pieces with knots suggest.

The textiles have been disposed in such a way not only to get rid of rubbish. Textiles stuffed in walls and under floors also have a practical function in thermal insulation of the building.

\section{Textile recycling for salt mining}

In the $1^{\text {st }}$ millennium BC, Hallstatt and Dürrnberg-Hallein in the Austrian Alps were important salt mines to provide the region with that vital commodity. Both of the mines offer the same product, but they have different working traditions. At Hallstatt (Kern et al. 2009), mining for salt is proved since Bronze Age (c. $15^{\text {th }}$ century BC), whilst the Dürrnberg (Stöllner 2002; 2005) salt deposit was used from the $6^{\text {th }}$ century BC onwards. Both salt mines offer excellent conditions for the preservation of organic material due to the high degree of salt penetration. Such the amount of leather, textile, wooden items is exceptional. Most fabrics are discovered in the so called "Heidengebirge", secondary rock-salt debris compressed together with waste of the salt production process. The layers completely fill up the old galleries. From Hallstatt, we know as well Bronze Age textiles from between 1500-1200 BC as well as a huge corps of Early Iron Age textiles from roughly between 900 and $400 \mathrm{BC}$, whilst the textile fragments discovered at Dürrnberg are slightly younger, most of them dating to the $5^{\text {th }}$ and $4^{\text {th }}$ century BC (general timespan $6^{\text {th }}-1^{\text {st }}$ century BC). 
Textiles in the salt mines are usually found as smaller torn fragments. So far, no complete garment could be found. The fragmentary state of the textiles often can be explained such as they already have been brought into the mine as rags (Stöllner 2005: 171; Reschreiter et al. 2009; Grömer et al. 2013, chapter 5). In the mines, they have then been used for different purposes, which are discussed in this chapter.

\section{Makeshift binding material}

Both from the Iron Age parts of the Hallstatt and Dürrnberg mines, textile scraps are known that have been intentionally torn into strips. Some of those pieces of fabric have knots, some of them are tied together. We also find conjunctions with bast material (Fig. 12) (Stöllner 2002: fig. 12, Taf. 4/1375, 5/1674; Reschreiter et al. 2009: fig. 6).

These fabrics were apparently used as a makeshift binding material. A particularly impressive example has been found from the Dürrnberg/Hinterseng site (Fig. 13) (Kyrle 1918: fig. 60). As early as the middle of the $19^{\text {th }}$ century, an elaborately coloured patterned fabric was discovered there, knotted around a broken tool handle. The primary purpose of this beautifully designed piece was likely as clothing; it was finally recycled and used for repair work. This find is lost since World War II, but from the recent excavations, many repaired tool handles have been found, usually with leather bands (Stöllner 2002, Taf. 109, 111 or 140).

In the salt mines Hallstatt and Dürrnberg, strings and ropes made of various tree basts and grasses were used primarily as binding materials. If these were not at hand, fabric strips, leather strips or even young elastic twigs were used (Stöllner 2002: Taf. 9-10; Kern et al. 2009: 64-65).

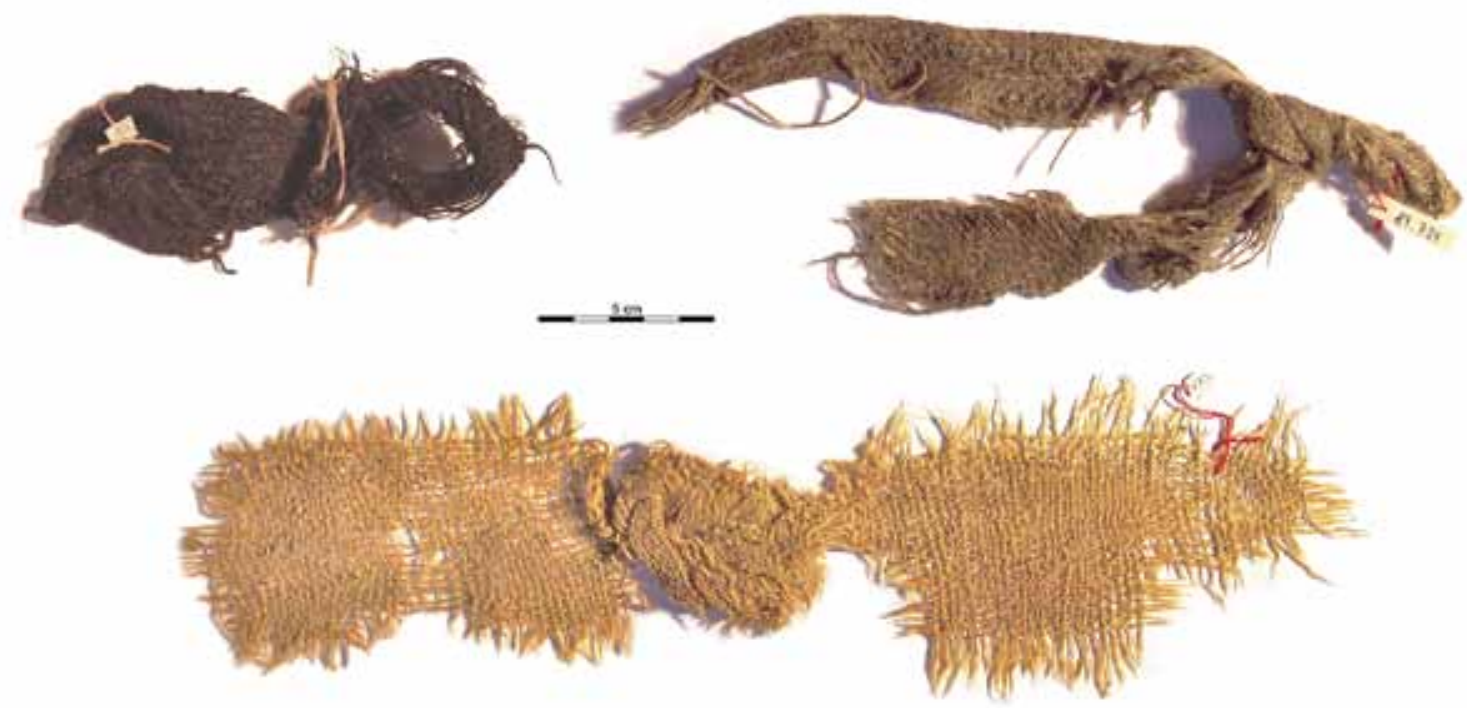

Fig. 12: Hallstatt salt mine, Austria: Iron Age textiles with knots (ㄷ Natural History Museum Vienna; photo: A. Rausch). 
Fig. 13: Dürrnberg salt mine, Austria: patterned textile as makeshift binding material for a broken tool handle (after: Kyrle 1918).
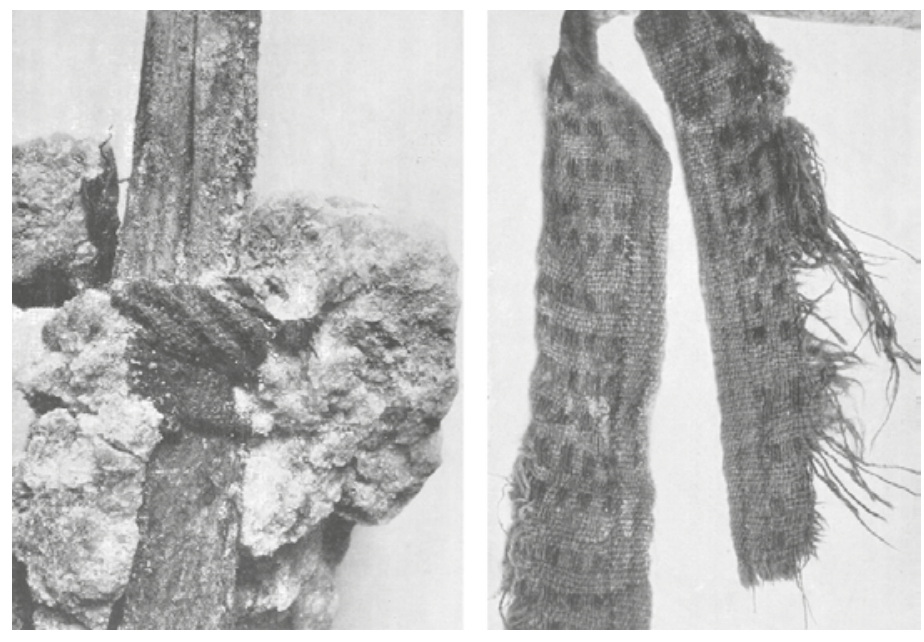

\section{Fixage for tools (Dürrnberg)}

Beside improvised binding material, also direct use in combination with tools can be identified. For salt mining, bronze picks have been employed with wooden handles. To ensure the hold of the bronze pick in the mounting, sometimes a thin layer of a flexible material was inserted between wood and bronze: sheets of leather (e.g. Stöllner 2002: Taf. 190). Those sheets have a characteristic rectangular form, usually measuring $12 \times 4 \mathrm{~cm}$. Maybe some of the textile rags found in the salt mines that are torn (or cut) into a rectangle, also served as fixing for a tool handle (e.g. Stöllner 2002, Taf. 120).

Such form of technical secondary use can also be postulated from a Late Bronze Age hoard in Sublaines, France. In the shaft of a bronze axe a piece of textile could be found. Hans-Jürgen Hundt (1988: 261) assumed that the fabric had the function of wedging the wooden handle in the spout of the axe.

In both cases, the textile can be interpreted as secure fixage of the tool.

\section{Wrapping, covering and hygienic properties}

At least, more evidence for textile recycling is subsumed under wrapping, covering and hygienic properties, for presenting some examples for further uses for textile scraps and rags.

\section{Wrapped objects in graves}

For Iron Age contexts a specific rite could be identified (see e.g. Banck-Burgess 1999; RastEicher 2008: 178-180), especially the wrapping of grave goods. Margarita Gleba (2014) recently set together more examples for the practice of textile wrapping, as they are documented especially in Italian graves:

* Wrapping or covering of the body with a funeral shroud

* Wrapping of the cremated remains placed in the urn

* Wrapping the urn containing cremated remains

* Wrapping of specific burial goods

* Wrapping of all objects in the burial. 
Fig. 14: Hallstatt cemetery, Austria: textile wrapped around a sword, Early Iron Age (C Natural History Museum Vienna; photo: A. Rausch).

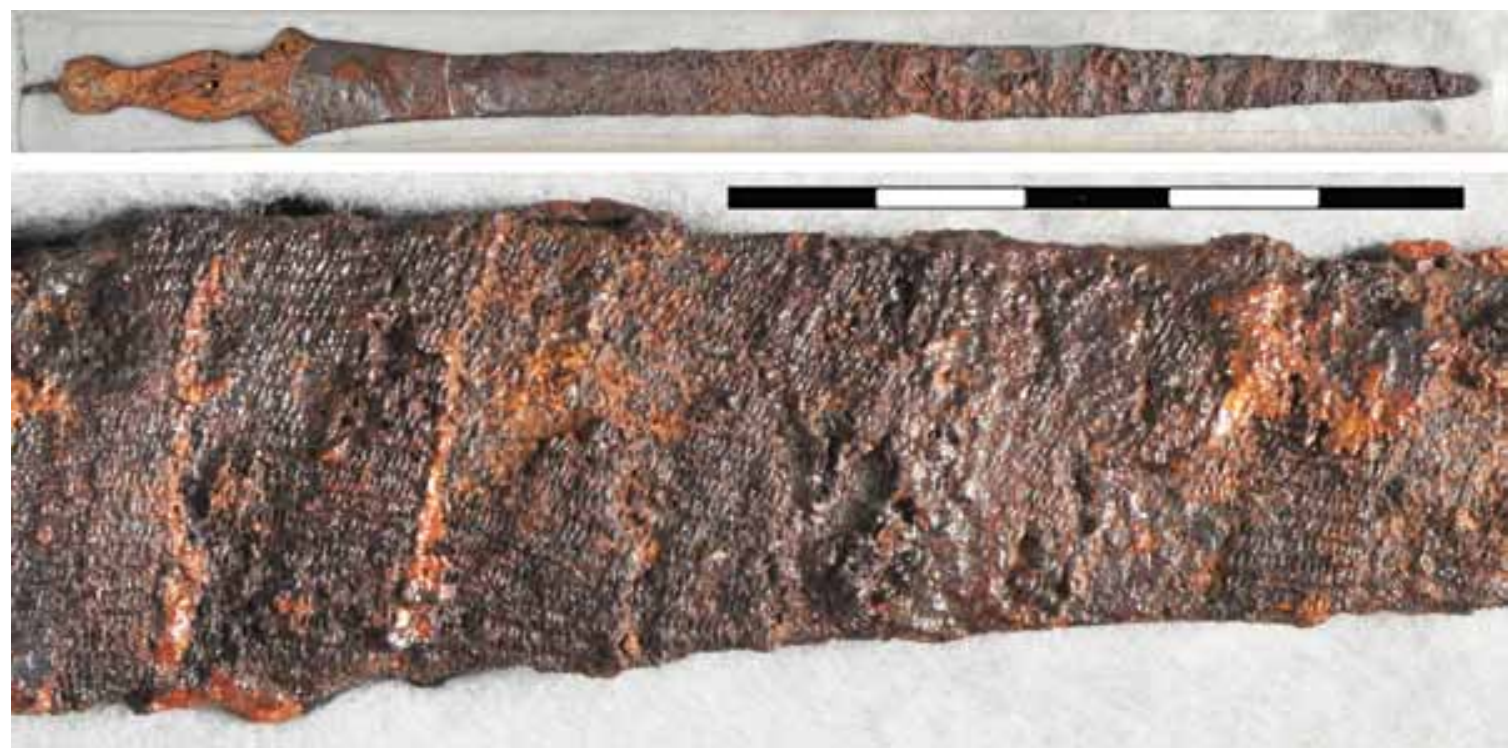

To give some examples from Central Europe: Specifically, knives, swords and other weapons were often heavily wrapped in the late Hallstatt and early La Tène periods (Rast-Eicher 2008: 178-180; Grömer 2014: 192-220). In the cemetery at Hallstatt (Fig. 14), it was documented that for some swords the iron blade was directly wrapped in textile bands (Kern 2005: fig. 10).

Various theories were discussed to explain this kind of archaeological evidence. The interpretative approaches are roughly divided into a functional-practical as well as a metaphysical intention. There may have been a taboo forbidding putting bare metal in the grave. Also some magical beliefs could be important such as to render the burial gifts invisible at the entrance to the otherworld (Banck-Burgess 2012b: 141-146). Among the practical reasons it was considered that envelopes may also be meant to protect valuable ingredients (Gleba 2014: 142). On the other hand, wrapping iron objects with textiles saturated with grease and oil might have served as protection against corrosion (e.g. Kern 2005: 8).

Unfortunately, we usually do not know whether the packaging material, the pieces of cloth, was made specifically for this purpose (primary use) or whether they were old, recycled textiles (secondary use).

\section{Sanitary properties and wound dressing}

Just in rare cases, there is some direct evidence that textile rags have been used for sanitary properties. One of them can be presented from the salt mine Dürrnberg (Stöllner 2005: fig. $12 / \mathrm{nr} .2817$ ), dating to the middle of the $1^{\text {st }}$ millennium BC. At the site Dürrnberg/FerroSchachtricht, $11 \mathrm{~cm}$ long bundle of a soft textile was excavated (Fig. 15). On closer examination, it was found that this soft, bright linen fabric was rolled up in the form of a finger and fixed in this form with a bast strip. It also contained a flat piece of wood. Obviously, the item served as finger bandage, a wound dressing for a finger. In the bundle also still unspecified plant remnants could be detected, which possibly served as blood stilling or support for wound healing. 


\section{Textile rags as "toilet paper"}

Even more hygienic uses have been discussed concerning textiles from the salt mine Dürrnberg. Probably, the material remains in the mountain were also used for various hygienic purposes, for example as cleaning rags or for cleaning hands and face, and possibly as a kind of "toilet paper" (Stöllner 2005: 162-164, fig. 3-4). Still, there is no conclusive evidence for the latter, even though human excrements have also been found in the salt mines.

More direct evidence is known from medieval and early modern latrine in cities and monasteries. For example, in a latrine of Stallburg, which is part of the imperial palace in Vienna, Austria, among other rubbish also some textiles have been excavated. They derive from various filling layers of the latrine, dating from the middle of the $16^{\text {th }}$ century AD. The preservation of the textiles is due to the rather acid environment in the latrine. The textiles are very fragmented and small, they have been made of woollen cloth in different qualities, coarse and fine ones. The context of a latrine is helpful for the interpretation of the textile remnants. Additionally, there are also clear indications for their intended use, because on some textiles, still brownish faecal remains (excrements) were attached (Fig. 16). Accordingly, the textile scraps were used as "toilet paper" in the latrine after their primary use.

This practice is by no means uncommon. As we learn from other textile finds from medieval and modern latrine, textile rags and scraps were often used for body hygiene. Examples can be named from the Augustinian monastery in Friborg im Breisgau, Germany (Banck 1992: 169171), or from the early modern latrine in Schatz-Haus Salzburg in Austria (Müllauer 2008: 207-210). From the Stallburg latrine only simple tabby fabrics were found, in contrast to this, in other cloacs, even more magnificent fabrics have been excavated. From cities like Lüneburg or Einbeck in Northern Germany (Tidow 2005) we have proof for precious textiles such as Atlas bindings, tapestry fragments, and silk ribbons, deriving from torn garments. Even those found their final use in a toilet.

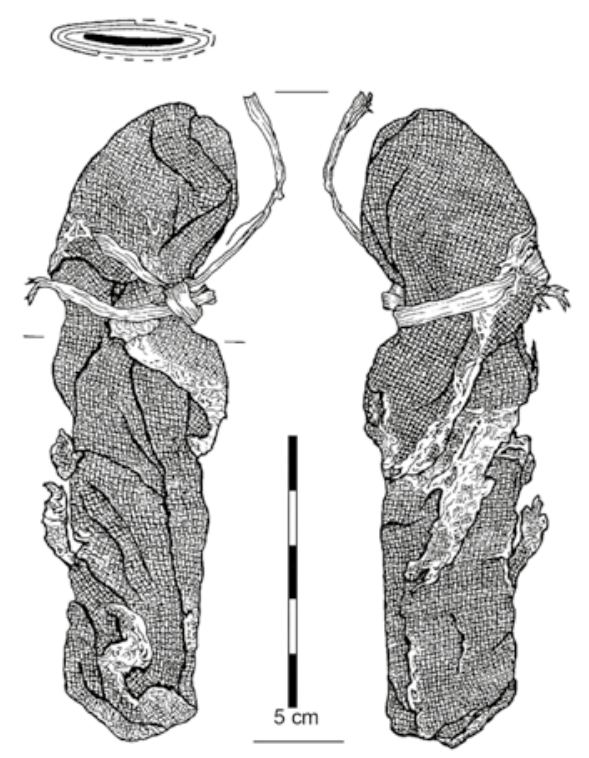

Fig. 15: Dürrnberg salt mine, Austria: Textile rag used as finger bandage (after: Ställner 2005).

Fig. 16: Vienna-Stallburg, Austria: Textile scrap found in a latrina with excrements still attached, $16^{\text {th }}$ century AD (photo: K. Grömer, Natural History Museum Vienna).

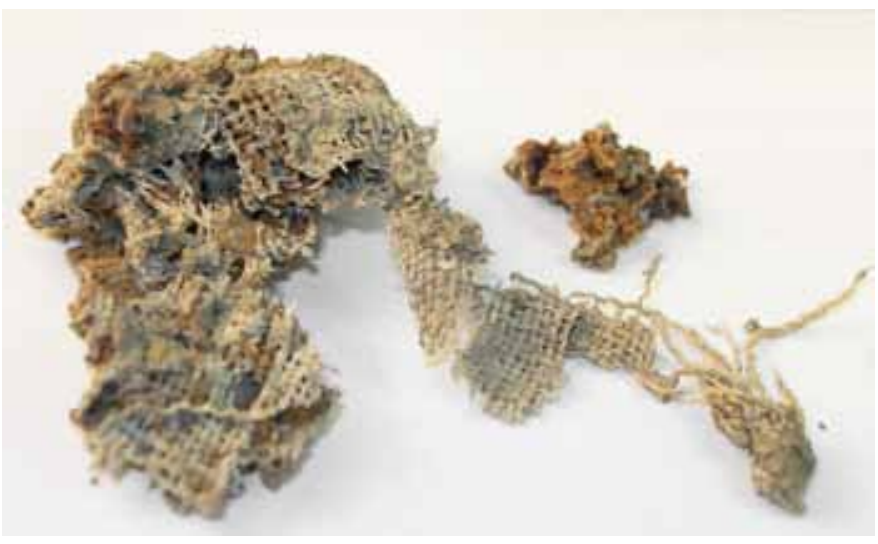


Fig. 17: Different kind of re-use and recycling of textiles between 1500 BC and 1500 AD (image: K. Grömer, Natural History Museum Vienna).

- Re-working of garments in prehistory

- Donations for liturgical

vestments

- Grave-garments

- Garments made of rags

- Other purposes

Garment

recycling
- Production of pottery

- Production of clay

figurines

- Production of jewellery and dress accessoires

- Briquetage

\section{Production of}

items

\section{Repair}

Re-use

Recycling

of Textiles

1500 BC -1500 AD
- Sealing for watermanagement

- Caulking wooden ships

- Insulation of medieval castles

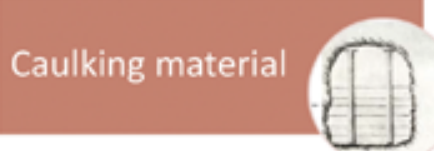

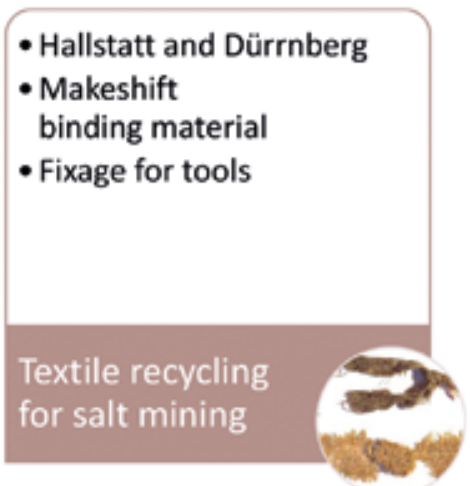

- Wrapped objects

in prehistoric graves

- Prehistoric wound dressing

- „Toilet paper"

Covering and

hygienic

properties 
Textile recycling today is seen as a method of reusing or reprocessing used clothing, fibrous material and clothing scraps from the manufacturing process. Prehistoric and historic examples presented are a small glimpse into repair, re-use and recycling of textiles in the past (Fig. 17). As exemplified, at least from Bronze Age on, we are able to trace back such behaviour. Recycling seems to be a common practice for most of human history (see also Rast-Eicher 2011), especially during periods when resources were scarce and hard to come by.

To apply modern systematics of textile recycling, as presented in the introduction, we can identify following cases in our historic study: "c) to use again in the original form or with minimal alteration" can only be proved with garments, e.g. when the function (dressing) is the same, but the context changed (daily life versus funeral use). "b) to alter or adapt for new use without changing the essential form or nature of" can be seen in cases, when e.g. garments have been repaired or patched.

Most textile fragments we discussed belong to the group "a) to treat or process (used or waste materials) so as to make suitable for reuse". As far as we can identify, worn out garments and other textiles have been torn or cut into desired shapes, sometimes stitched together and then used for different purposes. Those comprise all aspects of daily life - producing other items like pottery or bronze objects; for caulking; as makeshift binding material; for sanitary and hygienic purposes and many more.

An important task in modern textile recycling is "d) to pass through a cycle again; repeat a process from the beginning". That could not be identified among our historic material. This kind of uses of worn-out textiles would be e.g. for paper production (see e.g. Burns 1996; Rast-Eicher 2011: 22), what hasn`t been included into this study.

Today, in the Western World, the act of textile recycling often is motivated by a certain awareness of responsible use of natural resources, waste reduction as well as donating. Also, some economic factors can be named to re-use textiles (Joung \& Park-Poaps 2013).

Back in time, economic factors as well as optimizing natural resources might have been the main motivation for textile recycling. Even in prehistoric times we can assume a sense for careful resource-management, as in an impressive way given by examples from the saltmines Hallstatt and Dürrnberg. Not only with the textiles, but also with other material groups some sort of re-use can be stated. This is especially explored for Hallstatt, where also wooden tool handles and wooden vessels have been re-used (Reschreiter et al. 2009).

Here it is important to be aware that in pre-industrial times the production of textiles is quite time-consuming. To prepare the raw material, spin and weave a cloth of a certain size can last months (Andersson-Strand 2010). Therefore textiles are to be used as long and carefully as possible. Not only the time inherent in the production of textiles might have been a motivator to apply secondary uses, but also the material value of certain raw materials. Especially in Medieval and Early Modern, due to the expensive raw-materials used such as silk and gold, textiles also have been re-used in a high-ranked context and not only as rags and scraps. Interesting historic examples for such elite contexts are the donations of textiles to the church. Their reuse as ecclestical garments also demonstrates, that those textiles were not seen as used rags, but as a precious source.

Waste-reduction, as it is very important motivation for textile repair, re-use and recycling in the $21^{\text {st }}$ century, might not have been a primary motivation for people in the past. The awareness for ecologic problems is a more recent phenomenon. 


\section{Bibliography}

Andersson Strand, E. 2010. The Basis of Textile Tools and Textile Technology: From fibre to fabric. In: Textile Terminologies in the ancient Near East and Mediterranean from the third to the first millennia BC. (eds. C. Michel \& M.-L. Nosch). Ancient Textiles Series 8. Oxbow Books. Oxford. 10-22.

Banck, J. 1992. Die mittelalterlichen Textilfunde aus der Latrinengrube des Augustiner Klosters in Freiburg im Breisgau. In: Report from the 4th NESAT Symposium 1.-5. May 1990 in Copenhagen. Lise Bender Jørgensen und Else Munksgaard (Hrsg.). Copenhagen. 169-177.

Banck-Burgess, J. 2012a. Case Study: The Textiles from the Princely Burial at Eberdingen Hochdorf, Germany. In: Textiles and Textile Production in Europe from Prehistory to AD 400. (eds. M. Gleba \& U. Mannering). Ancient Textiles Series Vol. 11. Oxbow Books. Oxford. 139-152.

Banck-Burgess, J. 2012b. Instruments of Power. Celtic Textiles. Mittel der Macht. Textilien bei den Kelten. Theiss Verlag. Stuttgart.

Belanová, T. 2005. The state of research of La Tène Textiles from Slovakia and Moravia. In: "Hallstatt Textiles" Technical Analysis, Scientific Investigation and Experiment on Iron Age Textiles. (eds. P. Bichler et al.). British Archaeological Reports Int. Series 1351. Archaeopress. 175-189.

Belanová-Štolcová, T. 2012. Slovak and Czech Republic. In: Textiles and Textile Production in Europe from Prehistory to AD 400. (eds. M. Gleba \& U. Mannering). Ancient Textiles Series Vol. 11. Oxbow Books. Oxford. 306-333.

Bender Jørgensen, L. 1992. North European Textiles until AD 1000. Aarhus University Press. Aarhus.

Bergerbrant, S. 2007. Bronze Age Identities: Costume, Conflict and Contact in Northern Europe 1600-1300 BC. Stockholm Studies in Archaeology No. 43. Stockholm 2007.

Broholm, H. C. \& Hald, M. 1935. Danske Bronzealders Dragter. Nordiske Fortidsminder II. Copenhagen.

Burns, R. I. 1996. Paper comes to the West, 800-1400. In: Europäische Technik im Mittelalter. (ed. U. Lindgren). Gebr. Mann. Berlin. 413-422.

Catalogue St. Stephan 1997: 850 Jahre St. Stephan. Symbol und Mitte in Wieen 1147-1997. 226. Sonderausstellung der Stadt Wien, Dom- und Metropolitankapitel Wien 24. April bis 31. August 1997. Eigenverlag der Museen der Stadt Wien. Vienna.

Clegg Hyer, M. 2012. Reduce, Reuse, Recycle: Imagined and Reimagined Textiles in Anglo-Saxon England. In: Medieval Clothing and Textiles 8. (eds. R. Netherton \& G. Owen-Crocker). The Boydell Press. Woodbridge. 49-62.

Donin, L. 1873. Der Heilige Stefan und die Stefaner. Wien.

Engelhardt, C. 1865. Nydam Mosefund. Kjöbenhavn.

Eskildsen, L. \& Lomborg, E. 1977. Skørtejægere. Skalk. Vol. 1977/4. 4-6.

Farke, H. 2001. A typical costume of the North German Iron Age? Some observations during conservation of the Bernuthsfeld 'plaid'. In: The Roman Textile Industry and its Influence - A Birthday Tribute to John Peter Wild. (eds. P. Walton Rogers, L. Bender Jørgensen \& A. Rast-Eicher). Oxbow Books. Oxford. 129-136.

Gleba, M. 2008a. Textile Production in Pre-Roman Italy. Ancient textiles Series Vol. 4. Oxbow Books. Oxford.

Gleba, M. 2014. Wrapping Up for Safe Keeping: "Wrapping" Customs in Early Iron Age Europe. In: Wrapping and Unwrapping Material Culture. (eds. S. Harris \& L. Douny). Institute of Archaeology Publications 64, University College London. Left Coast Press. Walnut Creek. 135-146. 
Grömer, K. 2012. Austria: Bronze and Iron Ages. In: Textiles and Textile Production in Europe from Prehistory to AD 400. (eds. M. Gleba \& U. Mannering). Ancient Textiles Series Vol. 11. Oxbow Books. Oxford. 27-64.

Grömer, K. 2014. Römische Textilien in Noricum und Westpannonien - im Kontext der archäologischen Gewebefunde 2000 v. Chr. - 500 n. Chr. in Österreich. Austria Antiqua 5.. Uni Press Graz Verlag. Graz.

Grömer, K. 2016. The Art of Prehistoric Textile Making - The development of craft traditions and clothing in Central Europe. Veröffentlichungen der Prähistorischen Abteilung 5. Vienna.

Grömer, K., Kern, A., Reschreiter, H. \& Rösel-Mautendorfer, H. (eds.) 2013. Textiles from Hallstatt. Weaving Culture in Bronze and Iron Age Salt Mines. Textilien aus Hallstatt. Gewebte Kultur aus dem bronze- und eisenzeitlichen Salzbergwerk. Archaeolingua 29. Archaeolingua Publishers. Budapest.

Hald, M. 1980. Ancient Danish Textiles from Bogs and Burials. The National Museum of Denmark Vol. XI.

Hundt, H.-J. 1987. Textilreste aus awarischen Gräbern von Leobersdorf und ein Exkurs über gegossene Textilstrukturen an der Rückseite bronzener Riemenzungen. In: Das awarische Gräberfeld von Leobersdorf, NÖ. Studien zur Archäologie der Awaren 3/2. (ed. F. Daim). Wien. 9-17.

Hundt, H.-J. 1988. Ein Textilrest aus dem urnenfelderzeitlichen Deoptfund von Sublaines. Archäologisches Korrespondenzblatt 18. 261-263.

Inventory St. Stephan 2003. Kunstgutinventar Dom- und Metropolitanpfarre St. Stephan 2003. Inv. Nr. 2160, Ordner 48-57. Erzdiözese Wien - Referat für Kunst und Denkmalpflege, Diözesankonservatorin Dipl.-Ing. Hiltigund Schreiber.

Ipach, S. 2015. Prähistorische Salzherstellung. Der Fundort Erdeborn. Unpubl. Master-Arbeit Friedrich-Schiller-Universität Jena.

Ipach, S., Scherf, D. \& Grömer, K. 2014. Experimentelle Salzherstellung unter Verwendung von Textilien in spätbronze-/früheisenzeitlicher Briquetage. Archäologie Österreichs 25/2. Wien. 43-48.

Joung, H.-M. \& Park-Poaps, H. 2013. Factors motivating and influencing clothing disposal behaviours. International Journal of Consumer Studies 37 (2013). Blackwell Publishing Ltd,105111. doi: $10.1111 / \mathrm{j} .1470-6431.2011 .01048 . x$

Kaszab-Olschewski, T. 2015. „Fossilized Textiles“. In: Aspects of Design, Production and Use of Textiles and Clothing from the Bronze Age to the Early Modern Era. (eds. K. Grömer \& F. Pritchard). NESAT XII. The North European Symposium of Archaeological Textiles. 21 ${ }^{\text {st }}-24^{\text {th }}$ May 2014 in Hallstatt, Austria. Archaeolingua. Budapest. 201-208.

Kern, A. 2005. Hallstatt - eine Einleitung zu einem sehr bemerkenswerten Ort. In: Hallstatt Textiles - Technical Analysis, Scientific Investigation and Experiment on Iron Age Textiles. (eds. P. Bichler, K. Grömer, R. Hofmann-de Keijzer, A. Kern \& H. Reschreiter). British Archaeological Reports, International Series 1351. Archaeopress. 1-10.

Kern, A., Kowarik, K., Rausch, A. W. \& Reschreiter, H. 2009. Kingdom of Salt. Veröffentlichungen der Prähistorischen Abteilung 3. Verlag des Naturhistorischen Museums Wien. Wien.

Klose, O. 1916. Die prähistorischen Funde vom Mitterberge bei Bischofshofen im städtischen Museum Carolino-Augusteum zu Salzburg und zwei prähistorische Schmelzöfen auf dem Mitterberge. In: Österreichische Kunsttopographie XVII. (ed. G. Kyrle). Urgeschichte des Kronlandes Salzburg. Wien. 1-40.

Koide, Y. \& Tsuzuki, K. 2008. BORO - the BORO clothing culture of Aomori. Aspect publisher. 
Kostelníková, M. 1972. Velkomoravský textil $v$ archeologických nálezech na Moravě. (Grossmährische Textilien in archäologischen Funden aus Mähren). Studie arch. ústavu Československé Akad. v Brně 4. Brno.

Kyrle, G. 1918. Urgeschichte des Kronlandes Salzburg. Österreichische Kunsttopographie XVII. Wien. Beitrag I, S. 57.

Mannering, U., Gleba, M. \& Bloch Hansen, M. 2012. Denmark. In: Textiles and Textile Production in Europe from Prehistory to AD 400. (eds. M. Gleba \& U. Mannering). Ancient Textiles Series Vol. 11. Oxbow Books. Oxford. 91-121.

Möller-Wiering, S. 2011. War and Worship: Textiles from $1^{\text {st }}$ to $4^{\text {th }}$ century AD Weapon Deposits in Denmark and Northern Germany. Ancient Textiles Series Vol. 9. Oxbow Books. Oxford.

Möller-Wiering, S. \& Subbert, J. 2012. Germany: Roman Iron Age. In: Textiles and Textile Production in Europe from Prehistory to AD 400. (eds. M. Gleba \& U. Mannering). Ancient Textiles Series Vol. 11. Oxbow Books. Oxford. 153-185.

Müllauer, N. 2008. Die Textilfunde aus der frühneuzeitlichen Senkgrube im Schatz-Haus, Salzburg. In: Das Schatz-Haus in Salzburg. Archäologie und Geschichte eines salzburger Bürgerhauses. Archäologie in Salzburg 5/1. 207-226.

Müllauer, N. \& Ramsl, P. C. 2007. Herstellungstechnische Untersuchungen an Hohlblechreifen aus dem latènezeitlichen Gräberfeld von Mannersdorf am Leithagebirge, Niederösterreich. Archäologisches Korrespondenzblatt 37. 67-84.

Munksgaard, E. 1974. Oldtidsdragter. Nationalmuseet. Kobenhavn.

Nutz, B. 2015. "Ich brauch Hadern zu meiner Muel". In: Beiträge zur Mittelalterarchäologie in Österreich 31. 25-34.

Pieta, K. 1992. Keltische Textilreste mit Stickereien aus Nová Zámky, Südslowakei. In: Archaeological textiles in Northern Europe. Report from the $4^{\text {th }}$ NESAT Symposium 1990 in Copenhagen. Kopenhagen. 52-64.

Randsborg, K. 2011. Bronze Age Textiles. Men, Women and Wealth. Bristol Classical Press. London.

Rast-Eicher, A. 2008. Textilien, Wolle, Schafe der Eisenzeit in der Schweiz. Antiqua 44. Archäologie Schweiz. Basel.

Rast-Eicher, A. 2011. Recycling von Textilien. In: Nationale Informationsstelle zum Kulturerbe (NIKE), Bulletin 6. 20-23.

Reschreiter, H., Grömer K. \& Totschnig, R. 2009. Reich im Grab - Sparsam in der Grube. Überlegungen zum Ressourcenmanagement im ältereisenzeitlichen Salzbergwerk Hallstatt. In: Interpretierte Eisenzeiten. Fallstudien, Methoden, Theorie. (eds. R. Karl \& J. Leskovar). Studien zur Kulturgeschichte von Oberösterreich 22. 307-320.

Reschreiter, H. \& Kowarik, K. 2009: The everyday life of a miner. In: Kern, A., Kowarik, K., Rausch, A. W. \& Reschreiter, H. 2009a. Kingdom of Salt. Veröffentlichungen der Prähistorischen Abteilung 3. Verlag des Naturhistorischen Museums Wien. Wien. 57-59.

Rösel-Mautendorfer, H. 2013. Sewing techniques and design. In: Textiles from Hallstatt. Weaving Culture in Bronze and Iron Age Salt Mines. (eds. K. Grömer, A. Kern, H. Reschreiter \& H. RöselMautendorfer). Archaeolingua 29. Archaeolingua Publishers. Budapest. 99-118.

Schlabow, K. 1976. Textilfunde der Eisenzeit in Norddeutschland. Göttinger Schriften z. Vor- und Frühgeschichte 15. Karl Wachholtz Verlag. Neumünster.

Sporbeck, G. 2001. Die liturgische Gewänder 11. Bis 19. Jahrhundert. Bestandskatalog Museum Schnütgen. Sammlungen des Museum Schnütgen 4. Köln. 
Stöllner, Th. 2002. Der prähistorische Salzbergbau am Dürrnberg bei Hallein II. Die Funde und Befunde der Bergwerksausgrabungen zwischen 1990 und 2000. Dürrnberg-Forschungen Bd 3. Verlag Marie Leidorf. Rahden/Westf.

Stöllner, Th. 2005. More than Old Rags - Textiles from the Iron Age Salt-mine at the Dürrnberg. In: Hallstatt Textiles - Technical Analysis, Scientific Investigation and Experiments on Iron Age Textiles. (eds. P. Bichler, K. Grömer et al.). British Archaeological Reports, International Series S1351. Archaeopress. Oxford. 161-174.

Stöllner, Th., Thomas, P., Maass, A., Hornschuch, A., Pils, R. \& Röttger, K. 2009. Großproduktion für Kupfer im Raum Mitterberg in der Bronzezeit - Forschungsbericht für die Jahr 2008-2009. In: Die Geschichte des Bergbaues in Tirol und seinen angrenzenden Gebieten. Proc. 3. (K. Oeggl \& M. Prast Hrsg.). Milestone-Meeting SFB HiMAT 2008. Innsbruck. 231-242.

Stolleis, K. 2001. Messgewänder aus deutschen Kirchenschätzen vom Mittelalter bis zur Gegenwart. Schnell \& Steiner. Regensburg.

Tidow, K. 2005. Textilfunde aus dem 13.-17. Jahrhundert: Neue Funde - Neue Erkenntnisse? In: Northern Archaeological Textiles NESAT VII. (eds. F. Pritchard \& J.-P. Wild Hrsg.). Textile Symposium in Edinburgh, $5^{\text {th }}-7^{\text {th }}$ May 1999. Oxford. 98-101.

Van der Sanden, W. 1996. Through Nature to Eternity: The Bog Bodies of Northwest Europe. Batavian Lion International. Amsterdam.

Wild, J. P. 1970. Textile Manufacture in the Northern Roman Provinces. Cambridge University Press. Cambridge. 